\title{
URGENSI SEKOLAH PAUD UNTUK TUMBUH KEMBANG ANAK USIA DINI
}

\author{
RAIHANA \\ Pendidikan Islam Anak Usia Dini (PIAUD) Fakultas Agama Islam (FAI) \\ Universitas Islam Riau (UIR) \\ raihana@fis.uir.ac.id
}

\begin{abstract}
Early childhood education institutions are one form of early childhood education in formal education pathways for zero to six years. Early childhood education, in essence is education that is organized with the aim to facilitate the growth and development of children as a whole or emphasize the development of all aspects of the child's personality. Therefore, education for early childhood especially kindergarten needs to provide various activities that can develop various aspects of development which include cognitive, language, social, emotional and physical. Growth and development is a process that occurs in every living creature naturally. Growth will undergo physical changes while the development of changes in the structure and function of the body more complex. Children are individuals who are in a range of developmental changes ranging from infancy to adolescence.
\end{abstract}

Keywords: Urgency of Early Childhood Education, Child Growth.

\section{PENDAHULUAN}

Pendidikan memiliki makna
yang sangat penting dalam
menyiapkan manusia Indonesia
seutuhnya, membangun masa depan
anak-anak dan masyarakat
Indonesias eluruhnya. Pendidikan
hendaklah dilakukan sejak anak
berusia dini yang dapat dilakukan
oleh orang dewasa, baik orang tua
maupun guru sebagai tenaga
pendidik dilembaga formal.
Berdasarkan UU RI Nomor
20 Tahun 2003 Pasal 1 (dalam
Hasbullah, 2009:4), pendidikan

diartikan sebagai usaha sadar dan terencana untuk mewujudkan suasana belajar dan proses pembelajaran agar peserta didik secara aktif mengembangkan potensi dirinya untuk memiliki kekuatan spiritual kegamaan, pengendalian diri, kepribadian, kecerdasan, akhlak, mulia, serta ketrampilan yang diperlukan dirinya, masyarakat, bangsa dan Negara.

Fungsi Sekolah dalam masyarakat adalah sebagai berikut:
1. Sekolah sebagai lembaga pembaharu (agent of change), yang mengintrodaksi perubahan 
pengetahuan, cara berpikir, pola hidup, kebiasaan dan tata cara pergaulan, dan sebagainya.

2. Sekolah sebagai lembaga seleksi (selecting agency), yang memilih atau membeda-bedakan anggota masyarakat menurut kemampuan dan potensinya dalam memberikan pembinaan sesuai dengan kemampuan itu, agar setiap individu atau anggota masyarakat dapat mengembangkan potensinya semaksimal mungkin.

3. Sekolah sebagai lembaga peningkat (class leveling agency), yang membantu meningkatkan taraf sosial warga negara dan dengan demikian mengurangi atau menghilangkan perbedaan "kelas" dalam masyarakat.

4. Sekolah sebagai lembaga asimilasi (assimilating agency), yang berusaha mengurangi atau menghilangkan perbedaanperbedaan atas tradisi, adat dan kebudayaan, sehingga terdapat usaha penyesuaian diri yang lebih besar dalam persatuan dan kesatuan bangsa.

5. Sekolah sebagai lembaga pemeliharaan kelestarian (agent of preservation), yang memelihara dan meneruskan sifat-sifat budaya yang patut dipelihara dan diteruskan.

Pentingnya sekolah bagi anak selainakan mempengaruhi tumbuh kembang anak, karena mereka adalah calon-calon pemimpin bangsa masa depan. Selain itu, memperoleh pendidikan adalah merupakan salah satu hak anak yang tidak boleh kita abaikan.

Pemerintah Indonesia telah meratifikasi Konvensi Hak Anak melalui Keppres No. 36 tahun 1990 yang mengandung kewajiban negara untuk pemenuhan hak anak. Secara khusus, pemerintah juga telah mengeluarkan UU No. 20 tahun 2003 tentang Sistem Pendidikan Nasional, PP No. 27 tahun 1990 tentang Pendidikan Prasekolah serta PP No. 39 tahun 1992 tentang Peran Serta Masyarakat dalam Pendidikan Nasional. Untuk menegaskan komitmen pemerintah, bertepatan dengan Hari Anak Nasional 23 Juli 2003 Presiden Republik Indonesia Megawati Soekarno putri mencanangkan pelaksanaan Pendidikan Anak Usia Dini (PAUD) di Indonesia. Program kegiatan PAUD meliputi Posyandu, BKB (Bina Keluarga dan Balita), TK, TPA (Taman Penitipan Anak), Raudhatul Athfal (RA) dan Kelompok Bermain (KB).

Jalur dalam pendidikan anak usia dini terbagi menjadi tiga jalur pendidikan, yaitu:

1. Jalur Pendidikan Formal

Terdiri atas Taman Kanak-kanak dan Raudhatul Athfal.Termasuk disini adalah Bustanul Athfal. Taman Kanak-kanak dan Raudhatul Athfal dapat diikuti anak usia lima tahun keatas. 


\section{Jalur Pendidikan Non Formal}

Terdiri atas penitipan anak, Kelompok Bermain dan satuan PAUD sejenis. Kelompok Bermain dapat diikuti anak usia dua tahun keatas, sedangkan Penitipan Anak dan satuan PAUD Sejenis diikuti anak sejak lahir, atau usia tiga bulan.

3. Jalur Pendidikan Informal

Terdiri atas pendidikan yang diselenggarakan di keluarga dan di lingkungan. Ini menunjukkan bahwa pemerintah melindungi hak anak untuk mendapatkan layanan pendidikan, meskipun mereka tidak masuk ke lembaga pendidikan anak usia dini, baik formal maupun nonformal.

PAUD dari tahun ke tahun terus mengalami perkembangan yang pesat jika dilihat dari adanya peningkatan jumlah satuan Pendidikan Anak Usia Dini yang cukup signifikan yang diprakarsaioleh masyarakat secara mandiri di seluruh pelosok tanah air.

Sebagai contoh pertumbuhan TK, KB/RA, dan TPA di perkotaan lebih pesat dibandingkan di pedesaan dan rendahnya dukungan pemerintah dalam penyelenggaraan PAUD. Terdapat 41.317 buah TK di seluruh Indonesia, hanya 225 buah $(0.54 \%)$ TK yang didirikan oleh pemerintah, selebihnya dibangun oleh swasta.

Perkembangan ini bagian penting dari program utama pembangunan pendidikan nasional yang sudah di dukung oleh swasta (diprakarsaioleh masyarakat secara mandiri). Selanjutnya, berdasarkan Undang-undang No. 20 Tahun 2003 tentang Sistem Pendidikan Nasional pasal 1 angka 14 menyatakan bahwa PAUD adalah suatu upaya pembinaan yang ditujukan kepada anak sejak lahir sampai usia enam tahun yang dilakukan melalui pemberian rangsangan pendidikan untuk membantu pertumbuhan dan perkembangan jasmani dan rohani agar anak memiliki kesiapan dalam memasuki pendidikan lebih lanjut (Permendiknas 58 Tahun 2009).

Kartini Kartono (dalam Saring Marsudi, 2006: 6) mendiskripsikan karakteristik anak usia dini sebagai berikut :

1) Bersifat egoisentris naif

Pada usia ini anak memandang segala sesuatu dari sudut pandangannya sendiri, sesuai dengan pengetahuan dan pemahamannya sendiri, dibatasi oleh perasaan dan pikirannya yang masih sempit. Maka anak belum mampu memahami arti sebenarnya dari suatu peristiwa dan belum mampu menempatkan diri ke dalam kehidupan orang lain.

2) Relasi sosial yang primitif

Relasi sosial yang primitif merupakan akibat dari sifat egoisentris naif. Ciri ini ditandai oleh kehidupan anak yang belum dapat memisahkan antara dirinya dengan keadaan lingkungan sosialnya (benda-benda 
disekitarnya).

Anak pada masa ini hanya memiliki minat terhadap bendabenda atau peristiwa yang sesuai dengan daya fantasinya. Anak mulai membangun dunianya dengan khayalan dan keinginannya sendiri. Fantasi adalah kemampuan membentuk tanggapan baru dengan pertolongan tanggapan yang sudah ada.Imajinasi adalah kemampuan anak untuk menciptakan obyek atau kejadian tanpa didukung data yang nyata (Siti Aisyah, 2008). Anak usia dini sangat suka membayangkan dan mengembangkan berbagai hal jauh melampaui kondisi nyata. Bahkan terkadang mereka dapat menciptakan adanya teman imajiner. Teman imajiner itu bisa berupa orang, benda, atau pun hewan.

Adapun ciri khas dari Anak Usia Dini adalah sebagai berikut:

1. Sebagai bagian dari makhluk sosial.

Anak usia dini mulai suka bergaul dan bermain dengan teman sebayanya. Ia mulai belajar berbagi, mau menunggu giliran, dan mengalah terhadap temannya. Melalui interaksi sosial ini anak membentuk konsep dirinya. Ia mulai belajar bagaimana caranya agar ia bisa diterima lingkungan sekitarnya. Dalam hal ini anak mulai belajar untuk berperilaku sesuai tuntutan dari lingkungan sosialnya karena ia mulai merasa membutuhkan orang lain dalam kehidupannya.

2. Kesatuan jasmani dan rohani yang hampir tidak terpisahkan.

Anak belum dapat membedakan antara dunia lahiriah dan batiniah.Isi lahiriah dan batiniah masih merupakan kesatuan yang utuh.Penghayatan anak terhadap sesuatu dikeluarkan atau diekspresikan secara bebas, spontan dan jujur baik dalam mimik, tingkah laku maupun pura-pura, anak mengekspresikannya secara terbuka karena itu janganlah mengajari atau membiasakan anak untuk tidak jujur.

3. Sikap hidup yang fisiognomis Anak bersikap fisiognomis terhadap dunianya, artinya secara langsung anak memberikan atribut atau sifat lahiriah atau sifat konkrit, nyata terhadap apa yang dihayatinya. Kondisi ini disebabkan karena pemahaman anak terhadap apa yang dihadapinya masih bersifat menyatu (totaliter) antara jasmani dan rohani. Anak belum dapat membedakan antara benda hidup dan benda mati.Segala sesuatu yang ada disekitarnya dianggap memiliki jiwa yang merupakan makhluk hidup yang memiliki jasmani dan rohani sekaligus, seperti dirinya sendiri.

4. Merupakan pribadi yang unik Meskipun banyak kesamaan. 
dalam pola umum perkembangan anak usia dini, setiap anak memiliki kekhasan tersendiri dalam hal bakat, minat, gaya belajar, dan sebagainya. Keunikan ini berasal dari faktor genetis dan juga lingkungan. Untuk itu pendidik perlu menerapkan pendekatan individual dalam menangani anak usia dini.

5. Masa paling potensial untuk belajar.

Masa itu sering juga disebut sebagai "golden age" atau usia emas. Karena pada rentang usia itu anak mengalami pertumbuhan dan perkembangan yang sangat pesat di berbagai aspek. Pendidik perlu memberikan berbagai stimulasi yang tepat agar masa peka ini tidak terlewatkan begitu saja.Tetapi mengisinya dengan hal-hal yang dapat mengoptimalkan tumbuh kembang anak.

6. Memiliki rentang daya konsentrasi yang pendek (short attention span).

Anak usia dini memiliki rentang perhatian yang sangat pendek. Perhatian anak akan mudah teralih pada hal lain terutama yang menarik perhatiannya. Sebagai pendidik dalam menyampaikan pembelajaran hendaknya memperhatikan hal ini.

Menurut Soegeng (2000: 34) secara umum karakteristik anak usia dini atau prasekolah adalah suka meniru, ingin mencoba, spontan, jujur, riang, suka bermain, selalu ingin tahu (suka bertanya) banyak gerak, suka menunjukkan akunya (egois), unik, dan lain-lain. Snowman (dalam Patmonodewo, 2000:56), mengemukakan ciri-ciri anak usia dini meliputi aspek fisik, sosial, emosi dan kognitif anak. Menurut Snowman penampilan atau gerak-gerik anak usia dini (3-6 tahun) mudah dibedakan dengan anak yang berada dalam tahap sebelumnya.

Sedangkan menurut Siti Aisyah dkk. (2007: 56) mengatakan bahwa anak usia dini memiliki karakteristik yang khas, baik secara fisik, psikis, sosial, moral dan sebagainya. Masa kanak-kanak juga masa yang paling penting untuk sepanjang usia hidupnya. Sebab masa kanak-kanak adalah masa pembentukan pondasi dan dasar kepribadian yang akan menentukan pengalaman anak selanjutnya. Pengalaman yang dialami anak pada usia dini akan berpengaruh kuat terhadap kehidupan selanjutnya. Pengalaman tersebut akan bertahan lama, bahkan tidak dapat terhapuskan kalaupun bisa hanya tertutupi.

Pertumbuhan dan perkembangan adalah dua hal yang berbeda. Pertumbuhan adalah perubahan ukuran dan bentuk tubuh atau anggota tubuh, misalnya bertambah berat badan, bertambah tinggi badan, bertambah lingkaran kepala dan perubahan tubuh yang 
lainnya yang biasa disebut pertumbuhan fisik.Pertumbuhan dapat dengan mudah diamati melalui penimbangan berat badan atau pegukuran tinggi badan.Pemantauan pertumbuhan anak dilakukan secara terus menerus dan teratur.

\section{Adapun perkembangan}

adalah perubahan mental yang berlangsung secara berta hap dan dalam waktu tertentu, dari kemampuan yang sederhana menjadi kemampuan yang lebih sulit, misalnya kecerdasan, sikap, tingkah laku,dan sebagainya. Proses perubahan mental ini juga melalui tahap pematangan terlebih dahulu. Bila saat kematangan belum tiba maka anak sebaiknya tidak dipaksa untuk meningkat ke tahap berikutnya misalnya kemampuan duduk atau berdiri.

Pertumbuhan dan perkembangan masing-masing anak berbeda, ada yang cepat dan ada yang lambat, tergantung faktor bakat (genetik), lingkungan dan konvergensi (perpaduan antara bakat dan lingkungan). Oleh sebab itu perlakuan terhadap anak tidak dapat disama ratakan, sebaiknya dengan mempertimbangkan tingkat pertumbuhan dan perkembangan anak (Diktentis Diklusepa, 2003).

Proses tumbuh kembang yang merupakan proses utama, hakiki dan positif pada anak, merupakan suatu yang penting pada anak tersebut. Tahun-tahun pertama merupakan kurun waktu yang penting bagi tumbuh kembang fisik, perkembangan kecerdasan, ketrampilan motorik dan sosial, emosi, berjalan demikian cepatnya, sehingga dapat dikatakan bahwa keberhasilan tahun-tahun pertama sebagian besar menentukan masa depan anak tersebut, bila tidak terdeteksi secara nyata akan mengurangi kualitas sumber daya manusia kelak dikemudian hari.

Menurut Kemenkes RI (2010: 42), proses tumbuh kembang anak mempunyai beberapa ciri-ciri yang saling berkaitan, yaitu :

1. Perkembangan menimbulkan perubahan.

Perkembangan terjadi bersamaan dengan pertumbuhan.Setiap pertumbuhan disertai dengan perubahan fungsi. Misalnya, perkembangan intenlegensia pada seorang anak akan menyertai pertumbuhan otak dan serabut saraf.

2. Pertumbuhan dan perkembangan tahap awal menentukan perkembangan selanjutnya.

Setiap anak tidak akan bisa melewati satu tahap perkembangan sebelum ia melewati tahapan sebelumnya. Sebagai contoh, seorang anak tidak akan bisa berjalan sebelum ia bisa berdiri. Seorang anak tidak akan bisa berdiri jika pertumbuhan kaki dan bagian tubuh lain yang terkait dengan fungsi berdiri anak terhambat. Karena itu perkembangan awal ini 
merupakan masa kritis karena akan menentukan perkembangan selanjutnya.

3. Perkembangan merupakan hasil proses kematangan dan belajar.

Kematangan merupakan proses intrinsik yang terjadi dengan sendirinya, sesuai dengan potensi yang ada pada individu. Belajar merupakan perkembangan yang berasal dari latihan dan usaha. Melalui belajar, anak memperoleh kemampuan menggunakan sumber yang diwariskan dan potensi yang dimiliki anak.

4. Pertumbuhan dan perkembangan mempunyai kecepatan yang berbeda.

Sebagaimana pertumbuhan dan perkembangan mempunyai kecepatan yang berbeda-beda, baik dalam pertumbuhan fisik maupun perkembangan fungsi organ dan perkembangan pada masing-masing anak.

5. Pertumbuhan berkolerasi dengan perkembangan.

Pada saat pertumbuhan berlangsung cepat, perkembangan pun demikian, terjadi peningkatan mental, memori, daya nalar, asosiasi dan lain-lain. Anak sehat bertambah umur, bertambah berat dan tinggi badanya serta bertambah kepandaiannya

6. Perkembangan mempunyai pola yang tetap sehingga bisa diramalkan.

Tahap perkembangan seorang anak mengikuti pola yang teratur dan berurutan. Tahap-tahap tersebut tidak bisa terjadi terbalik, misalnya anak terlebih dahulu mampu membuat lingkaran sebelum mampu membuat gambar kontak, anak mampu berdiri sebelum berjalan dan sebagainya Sedangkan menurut Bredekamp \& Coople (dalam Siti Aisyah, dkk, 2007) Prinsip-prinsip perkembangan anak usia dini adalah sebagai berikut:

1. Perkembangan aspek fisik, sosial, emosional, dan kognitif anak saling berkaitan dan saling mempengaruhi satu sama lain.

2. Perkembangan fisik/motorik, emosi, sosial, bahasa, dan kognitif anak terjadi dalam suatu urutan tertentu yang relatif dapat diramalkan.

3. Terdapat persamaan pola perkembangan bagi semua anak. Dengan demikian perkembangan seorang anak dapat diramalkan. Perkembangan berlangsung dari tahapan umum ke tahapan spesifik, dan terjadi berkesinambungan.

4. Perkembangan berlangsung dalam rentang yang bervariasi antar anak dan antar bidang pengembangan dari masingmasing fungsi.

5. Pengalaman awal anak memiliki pengaruh kumulatif dan tertunda terhadap perkembangan anak.

6. Perkembangan anak berlangsung ke arah yang makin kompleks, 
khusus, terorganisasi dan terinternalisasi.

7. Perkembangan dan cara belajar anak terjadi dan dipengaruhi oleh konteks sosial budaya yang majemuk.

8. Anak adalah pembelajar aktif, yang berusaha membangun pemahaman-nya tentang lingkungan sekitar dari pengalaman fisik, sosial, dan pengetahuan yang diperolehnya.

9. Perkembangan dan belajar merupakan interaksi kematangan biologis dan lingkungan, baik lingkungan fisik maupun lingkungan sosial.

10. Bermain merupakan sarana penting bagi perkembangan sosial, emosional, dan kognitif anak serta menggambarkan perkembangan anak.

11. Perkembangan akan mengalami percepatan bila anak berkesempatan untuk mempraktikkan berbagai ketrampilan yang diperoleh dan memahami tantangan setingkat lebih tinggi dari hal-hal yang dikuasainya.

12. Anak memiliki modalitas beragam (ada tipe visual, auditif, kinestetik, atau gabungan dari tipe-tipe itu) untuk mengetahui sesuatu sehingga dapat belajar hal yang berbeda pula dalam memperlihatkan hal-hal yang diketahuinya.

13. Kondisi terbaik anak untuk berkembang dan belajar ada dalam komunitas yang menghargainya, memenuhi kebutuhan fisiknya, dan aman secara fisik dan fisiologis

Peran aktif orangtua sangat diperlukan agar anaknya dapat tumbuh dan berkembang dengan sehat dan cerdas, kongkritnya orangtua harus senantiasa memperhatikan, mengawasi serta memberikan fasilitas untuk pertumbuhan dan perkembangannya (Sudarna, 2014:146-147).

\section{PEMBAHASAN}

Menurut Pestalozzi,
pendidikan taman kanak-kanak
hendaknya menyediakan pengalaman
yang menyenangkan, bermakna, dan hangat seperti yang diberikan oleh orang tua di lingkungan rumah (dalam Masitoh, 2003: 41). Senada dengan hal tersebut, Solehudin (1997: 33) mengungkapkan bahwa secara umum pendidikan prasekolah dimaksudkan untuk menfasilitasi pertumbuhan dan perkembangan anak secara menyeluruh sesuai dengan norma-norma dan nilai-nilai kehidupan. Pendidikan prasekolah hendaknya tidak berorientasi akademik, tetapi hendaknya dapat menyediakan pengalamanpengalaman belajar bagi anak. Disamping itu program pendidikan prasekolah harus disesuaikan dengan kebutuhan, minat dan perkembangan anak.

Anak pada usia ini berada pada masa golden age karena pada 
masa inilah terdapat "masa peka" yang penyerapan pengetahuannya luar biasa. Hal ini sejalan dengan pendapat Benjamin S. Bloom seorang ahli pendidikan dari universitas Chicago yang menyatakan bahwa $80 \%$ perkembangan mental dan kecerdasan peserta didik berlangsung pada usia dini (Mudjito, dkk, 2012: 1).

Selanjutnya Bloom juga mengemukakan bahwa pertumbuhan sel jaringan otak pada anak usia 0-4 tahun mencapai 50\% (Mudjito, dkk, 2012: 2). Artinya bila pada usia tersebut otak anak tidak mendapatkan rangsangan yang maksimal maka segala tumbuh kembang anak baik fisik maupun mental tidak akan berkembang secara optimal. Dengan demikian, harusnya menjadikan masyarakat khususnya pendidik untuk memberikan stimulasi semaksimal mungkin pada masa usia dini, agar tujuan PAUD dapat tercapai.

Kenyataannya sampai saat ini Menurut Dyah Kumala Sari (2006: 2), sebagian besar orang tua dan guru tidak memahami akan potensi luar biasa yang dimiliki anak-anak pada usia itu. Keterbatasan pengetahuan dan informasi yang dimiliki orang tua dan guru, menyebabkan potensi yang dimiliki anak tidak berkembang. Oleh karena itu pendidikan usia dini, prasekolah dan taman kanak-kanak tidak boleh diabaikan atau dianggap sepele.
Bahkan pendidikan seorang anak sebaiknya dilakukan sejak anak itu masih berada dalam kandungan.

Ada dua tujuan diselenggarakannya pendidikan anak usia dini yaitu:

1. Tujuan utama

Membentuk anak Indonesia yang berkualitas, yaitu anak yang tumbuh dan berkembang sesuai dengan tingkat perkembangannya.

2. Tujuan penyerta

Membantu menyiapkan anak mencapai kesiapan belajar (akademik) di sekolah.

Menurut Sulistiyaningsih (2005) menyebutkan bahwa dampak kesiapan anak masuk sekolah yaitu anak yang siap masuk sekolah akan mendapat kemajuan dalam proses belajarnya serta anak tersebut tidak akan mengalami frustrasi di lingkungan akademik, dan dapat menyelesaikan tugasnya dengan baik. Lebih lanjut dalam Santrock (2012) mengatakan anak-anak yang mendapat kemajuan dalam proses belajarnya serta anak tersebut tidak akan mengalami frustrasi di lingkungan akademik dan dapat menyelesaikan tugasnya dengan baik akan membangun konsep diri yang baik, dan memiliki minat belajar yang tinggi dibandingkan pada anak yang mengalami hambatan dalam proses belajar.

Sedangkan fungsi PAUD adalah sebagai berikut:

1. Fungsi adaptasi/sosial yang berperan dalam membantu anak 
menyesuaikan diri dengan keadaan dan situasi di sekitarnya, kemudian di sesuaikan dengan kondisi dan situasi dirinya sendiri sebagai pengenaan berbagai pola sikap, prilaku, kebiasaan dan sifat orang di sekitar yang akan membantu anak untuk memahami aspek-aspek psikologis dari lingkungan sosial anak.

2. Fungsi pengembangan yang berperan dalam menumbuh kembangkan berbagai potensi yang dimiliki anak dengan memberi suatu situasi atau llingkungan edukatif sehingga potensi-potensi tersebut dapat berkembang optimal dan bermanfaat bagi anak itu sendiri dan lingkungannya.

3. Fungsi bermain, karena bermain merupakan hak anak sepanjang rentang hidupnya, melalui bermain anak dapat memperoleh banyak pengetahuan dan melalui kegiatan bermain neuron-neuron otak anak berkembang dengan sangat pesat.

Adapun pentingnya

pelayanan Pendidikan Anak Usia Dini (PAUD) adalah sebagai berikut:

1. PAUD sebagai titik sentral strategi pembangunan sumber daya manusia dan sangat fundamental.

2. PAUD memegang peranan penting dan menentukan bagi sejarah perkembangan anak selanjutnya, sebab merupakan pondasi dasar bagi kepribadian anak.

3. Anak yang mendapatkan pembinaan sejak dini akan dapat meningkatkan kesehatan dan kesejahteraan fisik maupun mental yang akan berdampak pada peningkatan prestasi belajar, etos kerja, produktivitas, pada akhirnya anak akan mampu lebih mandiri dan mengoptimalkan potensi yang dimilikinya.

4. Merupakan Masa Golden Age (Usia Keemasan). Dari perkembangan otak manusia, maka tahap perkembangan otak pada anak usia dini menempati posisi yang paling vital yakni mencapai $80 \%$ perkembangan otak.

5. Cerminan diri untuk melihat

keberhasilan anak dimasa mendatang. Anak yang mendapatkan layanan baik semenjak usia 0-6 tahun memiliki harapan lebih besar untuk meraih keberhasilan di masa mendatang. Sebaliknya anak yang tidak mendapatkan pelayanan pendidikan yang memadai membutuhkan perjuangan yang cukup berat untuk mengembangkan hidup selanjutnya.

\section{PENUTUP}

Pendidikan Anak Usia Dini (PAUD) adalah suatu upaya pembinaan yang ditujukan bagi anak sejak lahir sampai dengan usia enam tahun yang dilakukan melalui 
pemberian rangsangan pendidikan untuk membantu pertumbuhan dan perkembangan jasmani dan rohani agar anak memiliki kesiapan dalam memasuki pendidikan lebih lanjut

Pendidikan pada anak usia dini pada dasarnya meliputi seluruh upaya dan tindakan yang dilakukan pendidik dan orang tua dalam proses perawatan, pengasuhan dan pendidikan pada anak dengan menciptakan aura dan lingkungan dimana anak dapat mengeksplorasi pengalaman yang memberikan kesempatan kepadanya untuk mengetahui dan memahami pengalaman belajar yang diperolehnya dari lingkungan, melalui cara mengamati, meniru dan bereksperimen yang berlangsung secara berulang-ulang dan melibatkan seluruh potensi dan kecerdasan anak.

Jalur dalam pendidikan anak usia dini terbagi menjadi tiga jalur pendidikan, yaitu jalur pendidikan formal, jalur pendidikan non formal, dan jalur pendidikan informal.

Pendidikan anak usia dini merupakan salah satu bentuk penyelenggaraan pendidikan yang menitikberatkan pada peletakan dasar ke arah pertumbuhan dan perkembangan fisik (koordinasi motorik halus dan kasar), kecerdasan (daya pikir, daya cipta, kecerdasan emosi, kecerdasan spiritual), sosio emosional (sikap dan perilaku serta agama) bahasa dan komunikasi, sesuai dengan keunikan dan tahap- tahap perkembangan yang dilalui oleh anak usia dini. Ilmu yang diberikan dan diajarkan menjadi penentu bagi tahapan perkembangan selanjutnya.

Anak usia 0-6 tahun di Indonesia berjumlah 26,09 juta akan tetapi yang terlayani dalam PAUD di jalur pendidikan formal (TK/RA) baru sekitar dua juta anak sehingga peran pendidikan luar sekolah dalam membantu mengatasi masalah tersebut sangat penting dan mendesak.

Kurangnya anak usia dini yang mendapatkan layanan pendidikan disebabkan beberapa faktor diantaranya: (1) kurangnya kesadaran masyarakat akan pentingnya pendidikan pada anak usia dini; (2) masih terbatas dan tidak meratanya lembaga layanan PAUD yang ada di masyarakat terutama di pedesaan. (3) rendahnya dukungan pemerintah dalam penyelenggaraan pendidikan anak usia dini. Terdapat 41.317 buah TK di seluruh Indonesia, hanya 225 buah (0.54\%) TK yang didirikan oleh pemerintah, selebihnya dibangun oleh swasta.

\section{DAFTAR PUSTAKA}

Aisyah

Siti, dkk.2008. Perkembangan dan Konsep Dasar Pengembangan Anak Usia Dini. Jakarta: Universitas Terbuka. 
Cropley, A.1994. Creativity Intellegence: a concept of 'true' giftedness. Europoan Journal for High Ability.

Direktorat PADU. 2002. Acuan Menu Pada Pendidikan Anak UsiaDini (Menu Pembelajaran Generik) Jakarta: Direktorat PADUDitjen PLSP-Depdiknas.

Direktorat Tenaga Teknis (Diktentis Diklusepa). 2003. Pertumbuhan dan Perkembangan Anak Usia 0 - 6 Tahun. Jakarta: Ditjen PLSP - Depdiknas.

Dyah Kumala Sari. 2006. Sejarah dan Problematika Pendidikan, Istoria. Edisi Pertama.

Hasbullah. 2009. Dasar - Dasar Ilmu Pendidikan. Jakarta: Raja Grafindo Persada.

Kartini Kartono. 1986. Psikologi Anak, Jakarta: Mandar Maju.

Kemenkes RI. 2010. Stimulasi, Deteksi dan Intervensi Dini Tumbuh Kembang Anak. Jakarta: Depkes.

Marsudi Saring. 2006. Permasalahan Dan Bimbingan di Taman Kanak-Kanak. Semarang: FKIP UMS

Masitoh, dkk.2003. Pendekatan Belajar aktif di Taman Kanak-kanak.Jakarta: Departemen Pendidikan Nasional.

Solehuddin. 1997. Konsep Dasar Pendidikan Pra Sekolah.
Bandung: Fakultas Ilmu Pendidikan UPI.

Mudjito, dkk, 2012. Pendidikan Inklusif. Jakarta: Baduose Media.

Patmonodewo, Soemiarti. 2000. Pendidikan Anak Prasekolah. Jakarta: Rineka Cipta.

UU Permendiknas No 58 Tahun 2009,Tentang Standar Pendidikan Anak Usia Dini. Jakarta

Soetjiningsih, 1998, Tumbuh Kembang Anak: Jakarta, EGC.

Santrock, Jhon W. 2009. Child Development. 12th ed. New York: McGraw-Hil. 2012. LifeSpan Development. 13th edition.

University Of Texas. Dallas: McGraw-Hil.

Sulistiyaningsih.W 2005, Kesiapan Bersekolah Anak Ditinjau dari Jenis Pendidikan Pra Sekolah Anak dan Tingkat Pendidikan Orang Tua. Jurnal Psikolosia. Volume I - Juni 2005. Universitas Sumatera Utara (diakses tanggal 20 Februari 2018).

Sudarna, 2014.PAUD Pendidikan Anak Usia Dini Berkarakter. Yogyakarta: Solusi Distribusi. 